Most of the data given in this article, have been taken (some verbatim), from Luciani's "Human Physiology," Vol. 1, chapter on circulation of the blood, and from the annotations of Professor Antonelli to the anatomy of Hyrtl.

C. Volini, M.D., Chicago.

\section{QUESTIONABLE LONGEVITY OF THE BULGARIANS}

To the Editor:-Isn't it curious that generation after generation of medical men should continue apparently without question to accept Metchnikoff's statement about the longevity of the Bulgarians? I have heard his deductions questioned, but never his facts. Yet it should not require great acumen to infer that it would be extremely difficult to verify the ages of individuals among primitive peoples like those of eastern Europe.

My father was a missionary in Bulgaria for many years. He toured the country thoroughly and of course talked with any number of peasants. He has told me that one striking thing about peasant life in Bulgaria was the scarcity of old persons. People generally did not know their ages. But by inquiring about events they remembered, he was often able to make a good approximation. It was very rare that he found a person as old as 70 . Men and women alike would look to be in the late seventies or eighties when they were in the fifties. The extremely hard life, and the absence of modern sanitation and knowledge of hygiene made them prematurely old and left them an easy prey to disease.

Metchnikoff, I presume, simply repeated another of the old wives' tales that make up so large a part of the supposed information on diet. His statement seems to have been taken as seriously as the Third George's inquiry why hot water froze sooner than cold.

H. J. Haskell, Kansas City Star, Kansas City, Mo.

\section{Queries and Minor Notes}

Anoximots Communicatrons and queries on postal cards will not be noticed. Every letter must contain the writer's name and address, but these will be omitted, on request.

\section{TREATMENT OF GONORRHEA}

To the Editor:-In THE Journal (April 26, 1919, p. 1255) there appears an abstract of an article by Pineo and Baillie on the treatment of gonor rhea by pus vaccines. Will you please give me your opinion as to this treatment; and if favorable, the place where they may be abtained.

ANswER.-The vaccine mentioned above is not available for sale, as it was manufactured by the authors themselves for their own use. The treatment must be considered as being still in the experimental stage. It must also be noted that in this experiment there were no control cases treated with other vaccines. The authors, themselves, while claiming for it "incomparably better results" than with any vaccine previously used by them, recognize that only certain types of cases are benefited and that dangerous effects may result unless care is shown in selecting the cases and in the dosage There is also the danger of inoculating the patient with "other bodies besides active gonococcal antigen, such as spores, etc." Until more evidence is available as to the merits of pus vaccine, the standard treatment of gonorrhea, such as described, for instance, in the Manual of Treatment of Venereal Diseases, should be depended on by the average physician.

\section{PROTEOGEN}

To the Editor:-Is there available information concerning a product exploited by William S. Merrill Company under the title "Proteogen"? They market "proteogens" for twelve distinct conditions. Their clains are extravagant. I wish to know whether the Council has investigated the product and what has been the verdict.

$$
\text { F. J. Bomberger, M.D., Mapleton, Minn. }
$$

Answer.-Yes. See pages 109 and 128, this issue.

\section{Medical Education and State Boards of Registration}

\author{
COMING EXAMINATIONS \\ New Mexico: Santa Fe, July 14. Sec., Dr. R. E. McBride, Las
Cruces. \\ Convention of the Catholic Hospital Association
}

The Catholic Hospital Association of United States and Canada held its fourth annual convention at St. Francis Xavier's Academy, Chicago, June 25-27, Rev. Charles B. Motulinier presiding. The main discussions were in regard to the organization of the staff with frequent regular meetings, laboratory in charge of a properly trained person to cooperate in all diagnoses, and case records from physical examination to end-results, in charge of a trained historian backed by the management. A most effective means of con. ducting the general discussion was a questionnaire pamphlet containing numerous questions sent in before the convention and answered on the floor by committees of specialists previously appointed by the chair. No uncertainty was allowed to prevail concerning the catholic adherence to the moral law and principles of the Catholic Church relating to hospital practice. Over 250 of the 652 Catholic hospitals in the United States and Canada and over 500, or one-fifth, of the doctors practicing in Catholic hospitals were reported as having joined the association. In the near future district or state branches of the association sufficiently small to comprehend local conditions will be organized and the work of these local units will be in charge of Rev. M. F. Griffin of Youngstown, Ohio. A monthly bulletin will be issued beginning in October, 1919. A committee will be appointed to plan for a Catholic training school for supervisors of nurses and superintendents of hospitals. Rev. Charles B. Moulinier of Milwaukee was reelected president, and Dr. Bernard F. McGrath, secretary-treasurer. The next convention will be held in St. Paul, June 23, 24 and 25, 1920.

\section{Arizona January and April Examination}

Dr. Allen H. Williams, secretary of the Board of Medical Examiners of Arizona, reports the oral and written examination held at Phoenix, Jan. 7-8, 1919. The examination covered 10 subjects and included 100 questions. An average of 75 per cent. was required to pass. Of the 17 candidates examined, 16 passed, and 1 failed. The following colleges werc represented :

\begin{tabular}{|c|c|c|}
\hline College & $\begin{array}{l}\text { Year } \\
\text { Grad. }\end{array}$ & $\begin{aligned} \text { Pet } \\
\text { Cent. }\end{aligned}$ \\
\hline College of Physicians and Surgeons, Little Rock. & $(1908)$ & 75.3 \\
\hline $\begin{array}{l}\text { Chicago College of Medicine and Surgery...... } \\
\text { Hahnemann Med. Coll. and Hosp. Chicago }\end{array}$ & (1917) 84.6 , & \\
\hline Jenner Medical College ................ & $(1913)$ & $\begin{array}{l}86.9 \\
76\end{array}$ \\
\hline College of Physicians and Surgeons, Keokuk....... & $(1890)$ & 80.7 \\
\hline $\begin{array}{l}\text { Hospital Coilege of Medicine, Louisville............... } \\
\text { Kentucky School of Medicine }\end{array}$ & $(1896)$ & $80^{*}$ \\
\hline 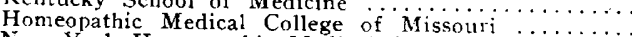 & $\begin{array}{l}(1893) \\
(1890)\end{array}$ & $\begin{array}{l}81.7 \\
96\end{array}$ \\
\hline New York Homeopathic Medical College and Hospital & $(1899)$ & $8 \div 3$ \\
\hline Eclectic Medical College $\ldots \ldots \ldots \ldots \ldots \ldots \ldots \ldots \ldots$ & (1918) & 87.3 \\
\hline $\begin{array}{l}\text { Ohio State University College of Medicine } \ldots \ldots \ldots \\
\text { Chattanooga Medical College }\end{array}$ & (1918) & \\
\hline Universities of Nashville and Tennessee. & $(19011)$ & 75.6 \\
\hline Southwestern University Medical College ............ & $(1907)$ & 87.3 \\
\hline School of Homeo. Med., Mexico .......... & & \\
\hline
\end{tabular}
John A. Creighton Medical College ............ (1906) 56.3
*The official records of the college named do not contain the name
of this applicant. $\uparrow$ No grade given.

The examination held at Phoenix, April 1-2, 1919, covered 10 subjects and included 100 questions. An average of 75 per cent. was required to pass. Ten candidates were examined, all of whom passed. The following colleges were represented:

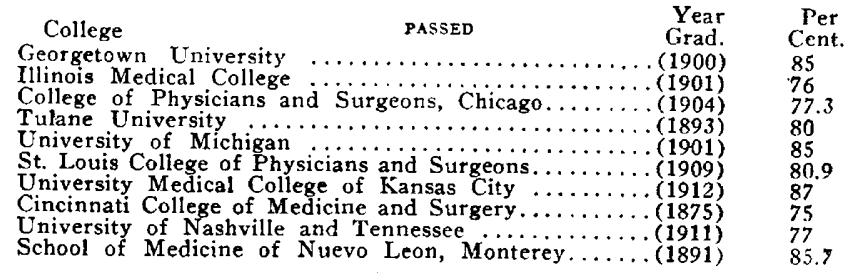

